(RESEARCH ARTICLE)

\title{
Economic valuation of ecosystem services of Eastern Corridor of Selous- Niassa ecosystem, Tanzania and Mozambique
}

\author{
Adili Y. Zella *
}

Department of Economic Studies, The Mwalimu Nyerere Memorial Academy, P.O Box 9193, Dar es Salaam, Tanzania.

Publication history: Received on 20 November 2020; revised on 01 December 2020; accepted on 05 December 2020

Article DOI: https://doi.org/10.30574/wjarr.2020.8.3.0455

\begin{abstract}
This paper explains the less known economic values of ecosystem services of Selous - Niassa ecosystem as a result of spatial and temporal changes of land use and land cover. Objectives of the study were to determine changes of ecosystem services, ecosystem functions, estimate ecosystem services of trees loss/gain and analyse ecosystem services of wood balance resulted from LULCC. The study employs benefit transfer method on local and global estimation of ESV with combination of field survey, remote sensing and GIS techniques Generally, annual changes of ESV for the period 1986 2016 estimated as US\$ 7 million and US\$ 20 million using local and global ESV coefficients respectively. Additionally, for three decades there is local and global annual loss of US\$322 million and US\$ 654 million respectively of ecosystem functions mostly from closed woodlands, open woodlands, grassland and water from 1986 to 2016. Also, there is total annual local and global gain of ecosystem functions of US\$ 106 million and US\$118 million respectively from bushland and cultivated land. The gain of ecosystem functions comes from provisioning services and the degradation of ecosystem functions led by, supporting services, then regulatory services and lastly cultural services. Furthermore, for the period 1986 - 2016 an annual ecosystem services of trees gained by US\$315 million and US\$ 642 million for local and global ESV respectively. Lastly, estimated local and global ESV of wood supply in the study area for the year 2016 is at least 25 times the average demand per year per capita. The study recommends an emergence of reviewing management and conservation strategies to attain sustainability of Selous-Niassa ecosystem.
\end{abstract}

Keywords: Ecosystem services; Land use and land cover; Ecosystem services of trees and Wood balance

\section{Introduction}

\subsection{Background Information}

Ecosystems provide services that are essential for life (Millennium Ecosystem Assessment, 2005; Raudsepp-Hearne et al., 2010; and Schmidt et al., 2016). These services support ecological processes and functions and provide resources for the survival of all organisms. There are four categories of ecosystem services includes; (i) provisioning services, (ii) supporting services, (iii) regulating services and (iv) cultural services (Ecosystem Assessment, 2005a; Food and Agriculture Organization, 1997 and TEEB, 2015). The values of these services are underestimated or ignored in commercial markets and decision making processes (Kahn, 2005; Pascual, 2010; and Schmidt et al., 2016). This scenario creates risks to natural capital due to probable negligence management (Schmidt et al., 2016). Economic valuation of ecosystem services (ES) is lively debated and finally argued that ES quantification in monetary terms harmonizes conservation strategies and economic objectives, accurately informs decision-makers and finally lessens environmental degradation(Laurans et al., 2013; Martin-Lopez et al., 2013; and Schmidt et al., 2016). Monetary valuation is seen as a powerful tool for decision making worldwide, but preferred to be vital in developing countries (COP, 2010; ten Brink et al., 2011; and Schmidt et al., 2016). Estimation of ES in monetary values combine a variety of interdisciplinary

\footnotetext{
* Corresponding author: Adili Y. Zella

Department of Economic Studies, The Mwalimu Nyerere Memorial Academy,P.0 Box 9193, Dar es Salaam, Tanzania. 
measurements in one unit, they are understandable and easily to communicate, and promise transferability across sites (Downing \& Ozuna, 1996; Smith \& Pattanayak, 2002; Schmidt et al., 2016; and Msofe et al., 2020)

ES are valued in prominent assessments of natural capital (Schmidt et al., 2016; and Msofe et al., 2020), in activities of economic development and poverty reduction (TEEB, 2015; SEEA, 2015 and WAVES, 2015), hazard mitigation programs (Miller, 2013 and Schmidt et al., 2016) and business studies (Elliot et al., 2014; Hanson et al., 2012; and Schmidt et al., 2016). The assessments of natural capital can be done through primary valuation methods that follow different economic approaches (travel cost, hedonic, production approaches, conjoint analysis, opportunity cost and replacement cost) and biome (land use proxy-based) method which is the benefit transfer approach (applies the use of the existing information of one area to a new one that has little or no information) (De Groot et al., 2012; Farber et al., 2006; Richardson et al., 2015 and Msofe et al., 2020). The benefit transfer approach is popular applied when there is scarcity of primary information and it is also time and cost effective. It provides first-hand information for decisionmakers on various aspects of policy actions and strategies for sustainable management of natural capital (Kreuter et al., 2001; Kubiszewski et al., 2017 and Wang et al., 2018). Besides, changes in patterns, scales and intensities of land use and land cover (LULC) types habituate ecosystem services (Tolessa et al., 2017 and Wang et al., 2017). These variations in LULC types in a given area can be used as a substitute for biomes to estimate values of ecosystem services of the area of interest (Kindu et al., 2016; Schmidt et al., 2016 and Msofe et al., 2020).

Global valuation of the ecosystem services and their changes proposed 17 types of ecosystem services coefficients of 16 biomes and their estimated ecosystem services values (TEEB, 2015). Also, various studies existed that value ecosystem services at the national level, state, or regional level based on proposed value coefficients (Kreuter et al., 2001; Hein et al., 2006; Troy \& Wilson, 2007; Liu and Costanza, 2010; Wang et al., 2018; Zhang et al., 2019 and Msofe et al., 2020). These value coefficients of different biomes employed through a benefit transfer approach together with remote sensing and GIS technologies to estimate the ecosystem services values (ESV) and mapping their distributions (Turner et al., 2002; Troy \& Wilson, 2007 and Msofe et al., 2020). This approach has been practical to estimate ESVs and suggests management options for regions with scarce data (Hein et al., 2006; Kindu et al., 2016 and Msofe et al., 2020). African countries including Tanzania and Mozambique suit the adaptation of this approach due to scarcity of data on values of ecosystem services.

Tanzania and Mozambique are characterized by rich, diverse and distinct terrestrial and marine ecosystems. Modification of habitat due to demographic and socio-economic processes is transforming the environment and often resulting in degrading ecosystems in these countries, causing disruption of the services they provide and biodiversity loss. For instance at the end of the year 2100, Tanzania's population will be nearly half a billion and will rise demand curve for natural resources that sustain the economy and livelihoods in the country, and serve as poverty safety nets in terms of food, water, energy, and shelter security (DENRM, 2010). The future demand of population will be greatest threat to the environment and will exceed ecosystem carrying capacity, unless natural resources are managed more sustainably.

Studies in Tanzania and Mozambique identified four human induced critically stressed ecosystem services that need immediate attention namely maintenance of biodiversity; food and fiber provision; water supply, purification and regulation; and fuel provision (International Institute for Sustainable Development for the United Nations Environment Programme, 2005). The main issues related to ecosystem degradation caused by human activities includes land-use change (linked to land conversion to agricultural use, deforestation and land degradation due to unsustainable practices), sedimentation and water pollution (linked to water overconsumption, agricultural run-off and soil erosion), and over harvesting/exploitation of natural resources (for small- and large-scale market and industry).

\subsection{Statement of the Problem}

Global land use and land cover change (LULCC) already affects the status and integrity of different ecosystems, leading to the loss of the ecosystem services and functions (Msofe et al., 2020; Gashaw et al., 2018; Tolessa et al., 2017; Kindu et al., 2016; Zorrillamiras et al., 2014; Degroot et al., 2012 and TEEB, 2010). The economic valuation of ecosystem services with LULCC assessments is vital for scientific researches because it raises awareness (Msofe et al., 2020; Gashaw et al., 2018 and Kreuter et al., 2001), provides information on the most valuable ecosystem services that need to be conserved (De Groot et al., 2012 and Liu et al., 2010), improves decision making for the allocation of scarce resources among competing needs and wants (Constanza et al., 2014; TEEB, 2010 and Daily, 1997), assists the formulation of policies and strategies that ensure sustainable management of an ecosystems (Tumer and Schaafsma, 2015 and Farber et al., 2006), and provides an efficient use of limited funds for conservation and restoration (Schmidt et al., 2016). The process of economic valuation of ecosystem services involves the estimation of the marginal value of ecosystem services that determines the costs of losing or the benefit of preserving a given amount or quality of an 
ecosystem service (Msofe et al., 2020; Pearce, 1998 and Schmidt et al., 2016). However there have been efforts to estimate values of ecosystem services for areas with scarce data, there are few studies on the ecosystem services valuation in relation to the LULCC dynamics in transfrontier conservation areas (TFCAs), such as Selous - Niassa TFCA.

Selous - Niassa TFCA is an ecosystem connected by the corridor between Selous Game Reserve (Tanzania) and Niassa National Reserve (Mozambique) making an area of $154000 \mathrm{~km}^{2}$ of natural miombo woodlands ecosystem. The TFCA consists a network of PAs of various categories of protection; an area of $110,000 \mathrm{~km}^{2}$ of this ecosystem is presently under conservation (Baldus and Hahn, 2009). The corridor connecting these two PAs to form TFCA is unprotected ecosystem. However, areas adjacent to TFCA PAs formulated WMAs (wildlife management areas) so as to involve community in conservation of wildlife outside PAs. Wildlife species use the corridor for migration and others adapted in the corridor due to its suitability for their climatic niche. Also, the corridor provides ecosystem services that are significant for local communities' wellbeing and livelihood (Zella et al., 2017). The corridor changes in land-use and production systems (e.g. extensification and intensification of agricultural production, transformation from subsistence use of natural resources to commercial practices) have consequences for ecosystems functioning and biodiversity, as habitats are transformed and fragmented. Degradation of natural forests does not only modify habitat and impact wildlife, but also climate and water catchment regulation capacity. The multiple and excessive use of ecosystem services and extraction of goods is increasing stress for the TFCA corridor of Selous-Niassa ecosystem in Tanzania and Mozambique.

Therefore, this study tries to fill the existing gap of economic values of ecosystem services of the corridors connecting TFCAs based on LULCC using eastern corridor of Selous-Niassa TFCA ecosystem as a case study.

\subsection{Objectives}

\subsubsection{Main objective}

The main objective of this study was to estimate economic value of ecosystem services of eastern corridor of SelousNiassa ecosystem.

\subsubsection{Specific objectives}

Specifically the study intends to

- determine changes of economic values of ecosystem services resulted from LULCC of eastern corridor of Selous-Niassa ecosystem from 1986 to 2016

- analyse changes of economic values of ecosystem functions based on LULC type of eastern corridor of SelousNiassa ecosystem from 1986 to 2016

- estimate changes of economic value of ecosystem services of trees loss/gain of eastern Selous-Niassa ecosystem from 1986 to 2016

analyse economic value of ecosystem services of wood balance of corridor dwellers of eastern Selous-Niassa ecosystem.

\section{Material and methods}

\subsection{Materials}

\subsubsection{Description of the Study Area}

The study was carried out in eastern Selous-Niassa TFCA with an area of 1,462,560 hectares called Selous-Niassa wildlife corridor (SNWC) which extends across southern Tanzania into northern Mozambique between $100 \mathrm{~S}$ to 110 40'S with north-south length of 160 to $180 \mathrm{~km}$ (Figure 1). SNWC comprises of two parts, western part (administratively passes in Namtumbo and Tunduru Districts of Ruvuma regions in southern Tanzania) and eastern part (administratively passes in Liwale, Nachingwea, Masasi, and Nanyumbu Districts). This study concentrated in eastern part. In eastern SNWC, migration of elephants, buffalos and zebras has been observed (Pesambili, 2003; Ntongani et al., 2007). Eastern SNWC comprises Msanjesi (2,125 ha) and the Lukwika-Lumesule (44,420 ha) Game Reserves in Masasi and Nanyumbu Districts respectively and areas of Liwale, Nachingwea, Masasi and Tunduru Districts. The study area comprise wildlife management areas (WMAs) bordering Selous, Msanjesi and Lukwika-Lumesule game reserves 
(MAGINGO WMA, NDONDA and MCHIMALU proposed WMAs respectively) which are within Liwale, Nachingwea/Masasi and Nanyumbu Districts respectively.

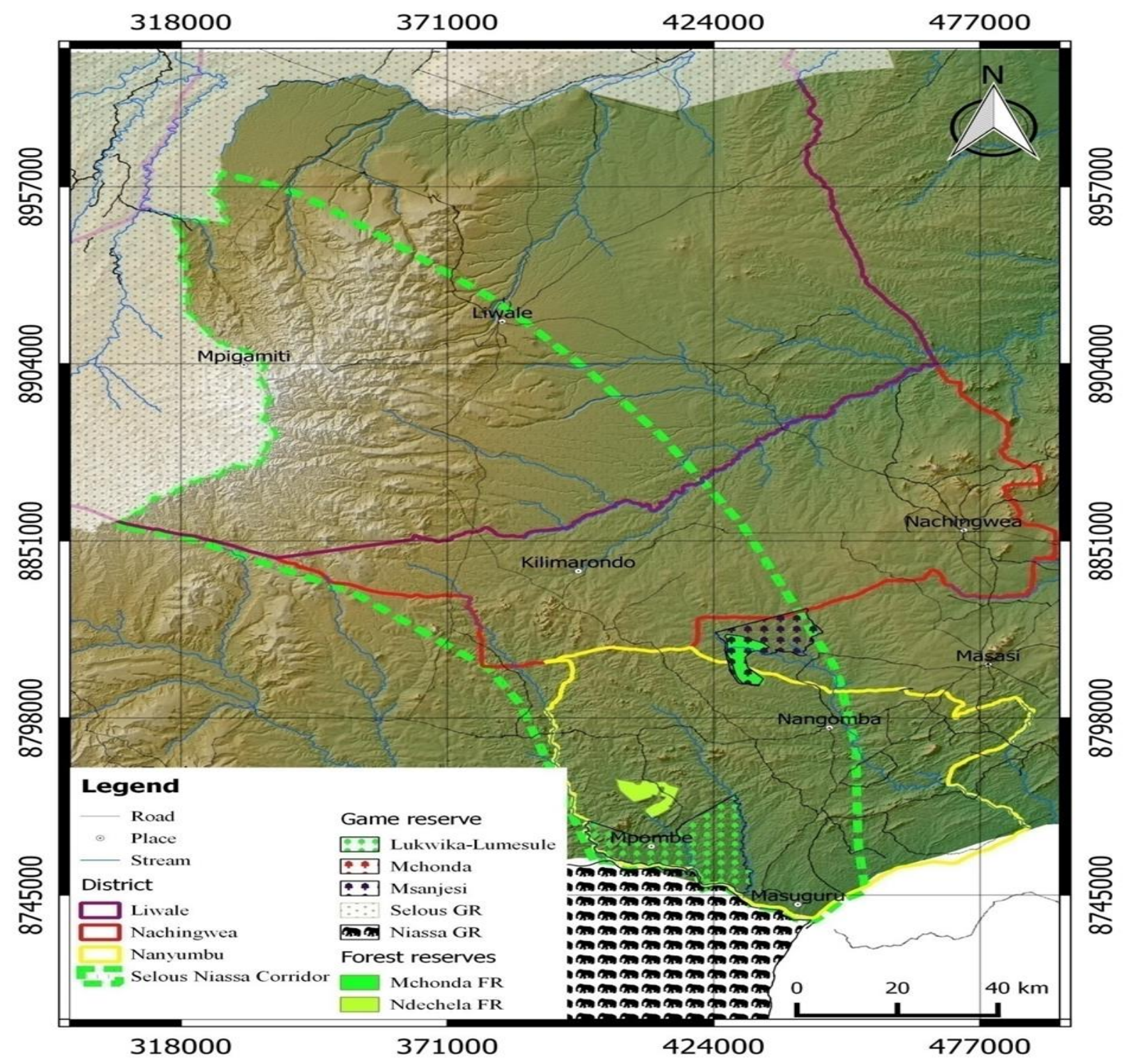

Figure 1 The Map of the study area.

\subsection{Data Used and Methods}

Figure 2 below shows the flow chart of the methodological approach used in this study for the estimation of the ecosystem service values (ESVs) for 1986, 1997, 2005 and 2016 years and the computation of changes between studies periods. 


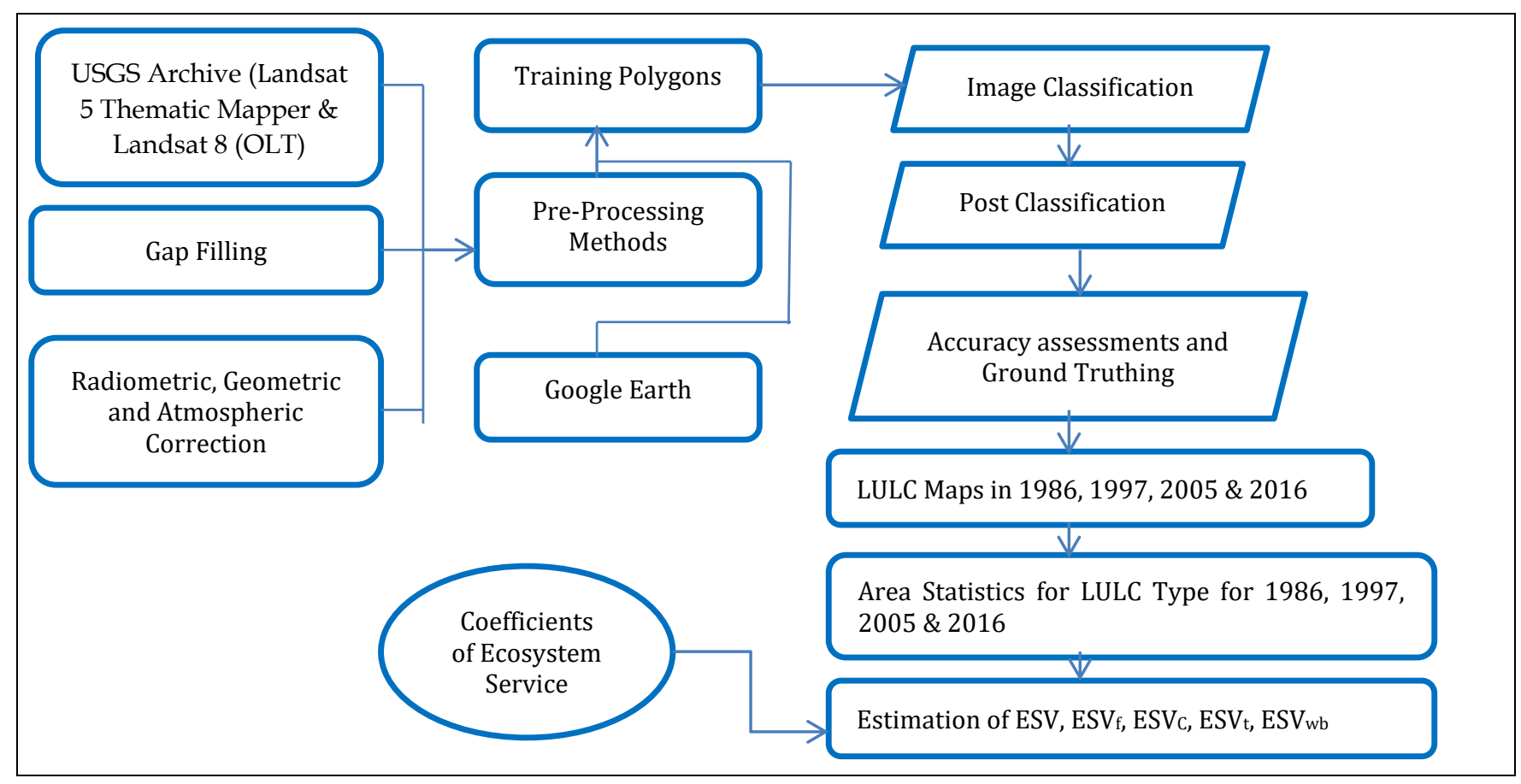

Figure 2 Flowchart of the methodological approach for this study

The LULC datasets were acquired from Zella et al., 2017 and biome equivalents with their corresponding ecosystem service value coefficients (VC) in 1994 US \$ ha-1year-1 for local and global VC shown in Table 1 as adapted from Kindu et al., 2016; Constaza et al., 1997 \&2014; and Msofe et al., 2020.

Table 1 Land use and land cover (LULC) types and biome equivalents with their corresponding ecosystem service value coefficients (VC)

\begin{tabular}{|c|c|c|c|c|c|c|c|}
\hline \multirow[b]{2}{*}{ LULC Type } & \multicolumn{4}{|c|}{ Year \& Area (ha) } & \multirow[b]{2}{*}{$\begin{array}{l}\text { Equivalent } \\
\text { Biome }\end{array}$} & \multirow{2}{*}{$\begin{array}{l}\text { Local (VC) } \\
1994 \quad \text { US\$ } \\
\text { ha-1 }^{-1} \text { year }^{-1}\end{array}$} & \multirow{2}{*}{$\begin{array}{ll}\begin{array}{l}\text { Global } \\
1994\end{array} & \text { (VC) } \\
\text { ha-1 }^{-1} \text { Uear-1 }^{-1} & \\
\text { b } & \end{array}$} \\
\hline & 1986 & 1997 & 2005 & 2016 & & & \\
\hline $\begin{array}{l}\text { Closed } \\
\text { woodland }\end{array}$ & 227731 & 244348 & 103198 & 89923 & Tropical Forest & 987 & 2008 \\
\hline Open woodland & 402201 & 411211 & 288176 & 220217 & Tropical Forest & 987 & 2008 \\
\hline Bushland & 433706 & 333399 & 256911 & 480269 & Tropical Forest & 987 & 244 \\
\hline Grassland & 394960 & 437621 & 515143 & 394461 & Grasslands & 293 & 244 \\
\hline Water & 1431 & 790 & 906 & 646 & Fresh water & 8103 & 8498 \\
\hline Built up area & 2532 & 3391 & 7623 & 8851 & Urban & 0 & 0 \\
\hline Cultivated land & 0 & 31799 & 290602 & 268193 & Cropland & 226 & 92 \\
\hline
\end{tabular}

This study employed the benefit transfer approach to estimate economic values of ecosystem services based on the adapted local and global VC of the ecosystem services for the targeted LULC types. Detailed ecosystem service functions and their global and modified local value coefficients of each LULC type are shown in Tables 2 \& 3 below as adapted from Msofe et al., 2020 and Constaza et al., 1997 \&2014. 
Table 2 Details of the ecosystem service functions and their modified local value coefficients for each LULC type (adapted from Msofe et al., 2020)

\begin{tabular}{|c|c|c|c|c|c|c|}
\hline \multirow[b]{2}{*}{ Ecosystem Services } & \multicolumn{6}{|c|}{ Each LULC Types of Ecosystem Service Values (1994 US\$ ha-1 year $^{-1}$ ) } \\
\hline & $\begin{array}{l}\text { Closed } \\
\text { woodland }\end{array}$ & $\begin{array}{l}\text { Open } \\
\text { woodland }\end{array}$ & Bushland & Grassland & Water & Cultivated land \\
\hline \multicolumn{7}{|l|}{ Provisioning services: } \\
\hline Water supply & 8 & 8 & 8 & & 2117 & \\
\hline Food production & 32 & 32 & 32 & 117.45 & 41 & 187.56 \\
\hline Raw material & 51.2 & 51.2 & 51.2 & & & \\
\hline Genetic resources & 41 & 41 & 41 & & & \\
\hline \multicolumn{7}{|l|}{ Medical services } \\
\hline Sub-total & 132.2 & 132.2 & 132.2 & 117.45 & 2158 & 187.56 \\
\hline \multicolumn{7}{|l|}{ Regulating services: } \\
\hline Water regulation & 6 & 6 & 6 & 3 & 5445 & \\
\hline Waste treatment & 136 & 136 & 136 & 87 & 431.5 & \\
\hline Erosion control & 245 & 245 & 245 & 29 & & \\
\hline Climate regulation & 223 & 223 & 223 & & & \\
\hline Biological control & & & & 23 & & 24 \\
\hline Gas regulation & 13.68 & 13.68 & 13.68 & 7 & & \\
\hline Disturbance regulation & 5 & 5 & 5 & & & \\
\hline Sub-total & 628.68 & 628.68 & 628.68 & 149 & 5876.5 & 24 \\
\hline \multicolumn{7}{|l|}{ Supporting services: } \\
\hline Nutrient cycling & 184.4 & 184.4 & 184.4 & & & \\
\hline Pollination & 7.27 & 7.27 & 7.27 & 25 & & 14 \\
\hline Soil formation & 10 & 10 & 10 & 1 & & \\
\hline Habitat/refugia & 17.3 & 17.3 & 17.3 & & & \\
\hline Sub-total & 218.97 & 218.97 & 218.97 & 26 & & 14 \\
\hline \multicolumn{7}{|l|}{ Cultural services: } \\
\hline Recreation & 4.8 & 4.8 & 4.8 & 0.8 & 69 & \\
\hline Cultural & 2 & 2 & 2 & & & \\
\hline Sub-total & 6.8 & 6.8 & 6.8 & 0.8 & 69 & \\
\hline Grand-total & 986.69 & 986.69 & 986.69 & 293.25 & 8103.5 & 225.56 \\
\hline
\end{tabular}


Table 3 Details of the ecosystem service functions and their global value coefficients for each LULC type (adapted from Constaza et al., 1997)

\begin{tabular}{|c|c|c|c|c|c|c|}
\hline \multirow[b]{2}{*}{ Ecosystem Services } & \multicolumn{6}{|c|}{ Each LULC Types of Ecosystem Service Values (1994 US\$ ha-1year-1) } \\
\hline & $\begin{array}{l}\text { Closed } \\
\text { woodland }\end{array}$ & $\begin{array}{l}\text { Open } \\
\text { woodland }\end{array}$ & Bushland & Grassland & Water & $\begin{array}{l}\text { Cultivated } \\
\text { land }\end{array}$ \\
\hline \multicolumn{7}{|l|}{ Provisioning services: } \\
\hline Water supply & 8 & 8 & 8 & & 3800 & \\
\hline Food production & 32 & 32 & 32 & 67 & 258 & 54 \\
\hline Raw material & 315 & 315 & 315 & 106 & & \\
\hline Genetic resources & 41 & 41 & 41 & & & \\
\hline \multicolumn{7}{|l|}{ Medical services } \\
\hline Sub-total & 396 & 396 & 396 & 173 & 4058 & 54 \\
\hline \multicolumn{7}{|l|}{ Regulating services: } \\
\hline Water regulation & 6 & 6 & 6 & 3 & 15 & \\
\hline Waste treatment & 87 & 87 & 87 & 87 & 4177 & \\
\hline Erosion control & 245 & 245 & 245 & 29 & & \\
\hline Climate regulation & 223 & 223 & 223 & & & \\
\hline Biological control & & & & 23 & & 24 \\
\hline Gas regulation & & & & 7 & 133 & \\
\hline Disturbance regulation & 5 & 5 & 5 & & 4539 & \\
\hline Sub-total & 566 & 566 & 566 & 149 & 8864 & 24 \\
\hline \multicolumn{7}{|l|}{ Supporting services: } \\
\hline Nutrient cycling & 922 & 922 & 922 & & & \\
\hline Pollination & & & & 25 & & 14 \\
\hline Soil formation & 10 & 10 & 10 & 1 & & \\
\hline Habitat/refugia & & & & & 304 & \\
\hline Sub-total & 932 & 932 & 932 & 26 & 304 & 14 \\
\hline \multicolumn{7}{|l|}{ Cultural services: } \\
\hline Recreation & 112 & 112 & 112 & 2 & 574 & \\
\hline Cultural & 2 & 2 & 2 & & 881 & \\
\hline Sub-total & 114 & 114 & 114 & 2 & 1455 & 0 \\
\hline Grand-total & 2008 & 2008 & 2008 & 350 & 14681 & 92 \\
\hline
\end{tabular}

\subsection{Data analysis}

2.3.1. To determine changes of economic values of ecosystem services resulted from LULCC of eastern corridor of SelousNiassa ecosystem from 1986 to 2016.

The LULC datasets shown in Table 1 used and the total value of ecosystem services in the study area for 1986, 1997, 2005 and 2016 was calculated by multiplying the area of a given LULC type by the corresponding modified ecosystem 
service value coefficients that were extracted from weight factors of the ecosystem services per hectare of each biome, see equation (1) adapted from Msofe et al., 2020 and Constaza et al., 1997 \& 2014 as follows:

$$
\mathrm{ESV}=\sum_{k=0}^{k}(\mathrm{Ak}+\mathrm{VCk})
$$

Where ESV = the total estimated ecosystem service value, $\mathrm{Ak}=$ the area (ha) and VCk = the value coefficient (US\$ ha-1 year-1) for LULC type ' $\mathrm{k}$ '. The ESVs for all land use and land cover (LULC) types were calculated. Besides, the change in the ESVs was determined by calculating the differences between the estimated values for each LULC category in 1986, 1997, 2005 and 2016. The percentage changes in the ESVs between the years were calculated based on the equation below:

$$
\text { Percentange ESV }=\frac{\left(\mathrm{ESVt}_{2}-\mathrm{ESVt}_{1}\right)}{\mathrm{ESVt}_{1}} \times 100
$$

Were ESVt2 (US\$ ha-1 year-1) = the estimated ecosystem service value in the most recent year, and ESVt1 (US\$ ha-1 year-1) = the estimated ecosystem service value in the previous year. Positive values suggest an increase in the ESVs, whereas negative values imply a decrease in the ESVs.

2.3.2. To analyse changes of economic values of ecosystem functions based on LULC type of eastern corridor of Selous-Niassa ecosystem from 1986 to 2016

Estimated values of the services provided by individual ecosystem functions within the study area using the following equation:

$$
\mathrm{ESVf}=\sum_{\mathrm{k}=0}^{\mathrm{k}}\left(\mathrm{Ak} * \mathrm{VC}_{\mathrm{fk}}\right)
$$

Where $\mathrm{ESV}_{\mathrm{f}}$ is the estimated ecosystem service value of function $\mathrm{f}, \mathrm{Ak}$ is the area (ha) and $\mathrm{VC}_{\mathrm{fk}}$ is the value coefficient of the function (US\$ ha-1 year-1) for LULC category ' $\mathrm{k}$ '. The contributions of the individual ecosystem functions to the overall value of the ecosystem services per year were calculated and summarized in the tables.

2.3.3. To estimate changes of economic value of ecosystem services of trees loss of eastern Selous-Niassa ecosystem from 1986 to 2016

Estimated amount of land (in hectares) that has been converted from closed and open woodlands to other socioeconomic activities was used to estimate number of trees loss. The study area belongs to southern zone as classified by URT (2015). The number of trees and volume per hectare of the distribution of forest and woody vegetation resources have been classified by employing methodology used by NAFORMA in URT (2015) as described much by Zella et al., 2017 of having average mean volume $\left(\mathrm{m}^{3} / \mathrm{ha}\right)$ and average number of trees/ha of 49.3 and 1,654 respectively. Then average mean volume $\left(\mathrm{m}^{3} / \mathrm{ha}\right)$ and average number of trees/ha were assigned modified ecosystem service value coefficients that were extracted from weight factors of the ecosystem services per hectare as adapted from Msofe et al., 2020. This was used also to estimate ecosystem service value of individual tree found in the study area.

2.3.4. To analyse economic value of ecosystem services of wood balance of corridor dwellers of eastern Selous-Niassa ecosystem

Human population of corridor dwellers was estimated based on NBS (National Bureau of Statistics), 2012 census and computing average demand for wood compared with supply from the corridor ecosystem as described much by Zella et al., 2017. Then obtained information of wood balance were assigned modified ecosystem service value coefficients and get ecosystem services of wood balance of corridor dwellers of eastern corridor of Selous-Niassa ecosystem. 


\section{Results and discussion}

\subsection{Changes of Economic Values of Ecosystem Services Resulted From LULCC of Eastern Corridor of Selous- Niassa Ecosystem from 1986 to 2016}

3.1.1. Status of Economic Values of Ecosystem Services for Biome in Each LULC Type of Eastern Corridor of Selous-Niassa Ecosystem from 1986 to 2016

Economic values of ecosystem services using local value coefficients for biome in each land use land cover (LULC) type for the year 1986, 1997, 2005 and 2016 are presented in Table 4. Generally, results show variations in ecosystem services values between four periods under consideration. There is a decrease in economic value of ecosystem services of at least 18\% equivalent US\$ to around 216 million from 1986 to 2016.

Table 4 Local Ecosystem Services Values (ESV) year-1 distribution between 1986 and 2016.

\begin{tabular}{|l|l|l|l|l|l|l|l|l|}
\hline \multirow{2}{*}{ LULC } & \multicolumn{2}{l}{$\mathbf{1 9 8 6}$} & $\mathbf{1 9 9 7}$ & $\mathbf{2 0 0 5}$ & $\mathbf{2 0 1 6}$ \\
\cline { 2 - 9 } & $\mathbf{( E S V )}$ & $\mathbf{( \% )}$ & $\mathbf{( E S V )}$ & $\mathbf{( \% )}$ & $\mathbf{( E S V )}$ & $\mathbf{( \% )}$ & (ESV) & (\%) \\
\hline Closed woodland & 224770497 & 19.1 & 241171476 & 21.6 & 101856426 & 11.8 & 88754001 & 9.2 \\
\hline Open woodland & 396972387 & 33.7 & 405865257 & 36.3 & 284429712 & 32.9 & 217354179 & 22.6 \\
\hline Bushland & 428067822 & 36.4 & 329064813 & 29.4 & 253571157 & 29.4 & 474025503 & 49.3 \\
\hline Grassland & 115723280 & 9.8 & 128222953 & 11.5 & 150936899 & 17.5 & 115577073 & 12.0 \\
\hline Water & 11595393 & 1.0 & 6401370 & 0.6 & 7341318 & 0.8 & 5234538 & 0.5 \\
\hline Built up area & 0 & 0 & 0 & 0.0 & 0 & 0.0 & 0 & 0.0 \\
\hline Cultivated land & 0 & 0 & 7186574 & 0.6 & 65676052 & 7.6 & 60611618 & 6.3 \\
\hline TOTAL & 1177129379 & 100.0 & 1117912443 & 100.0 & 863811564 & 100.0 & 961556912 & 100.0 \\
\hline
\end{tabular}

Table 5 shows economic values of ecosystem services using global value coefficients for biome in each land use land cover (LULC) type for the year 1986, 1997, 2005 and 2016. Results show high variations in ecosystem services values between four periods under consideration compared to local values of ecosystem services indicated in Table 4. Economic values of ecosystem services decreases for about 41\% amounted approximately US\$ 612 million from 1986 to 2016. The global ESV overpass local ESV for about $20.4 \%$ (US\$ 302 million), 26.2\% (US\$ 396 million), $14.4 \%$ (US\$ 145 million) for the year 1986, 1997 and 2005 respectively; and underpass for about 11\% (US\$ 95 million) for the year 2016.

Table 5 Global Ecosystem Services Values (ESV) distribution between 1986 and 2016

\begin{tabular}{|l|l|l|l|l|l|l|l|l|}
\hline \multirow{2}{*}{ LULC } & $\mathbf{1 9 8 6}$ & $\mathbf{1 9 9 7}$ & $\mathbf{2 0 0 5}$ & $\mathbf{2 0 1 6}$ & \multicolumn{4}{|l|}{} \\
\cline { 2 - 9 } & $\mathbf{( E S V )}$ & $\mathbf{( \% )}$ & $\mathbf{( E S V )}$ & $\mathbf{( \% )}$ & $\mathbf{( E S V )}$ & $\mathbf{( \% )}$ & (ESV) & (\%) \\
\hline Closed woodland & 457283848 & 30.9 & 490650784 & 32.4 & 207221584 & 20.5 & 180565384 & 20.8 \\
\hline Open woodland & 807619608 & 54.6 & 825711688 & 54.5 & 578657408 & 57.4 & 442195736 & 51.0 \\
\hline Bushland & 105824264 & 7.2 & 81349356 & 5.4 & 62686284 & 6.2 & 117185636 & 13.5 \\
\hline Grassland & 96370240 & 6.5 & 106779524 & 7.1 & 125694892 & 12.5 & 96248484 & 11.1 \\
\hline Water & 12160638 & 0.8 & 6713420 & 0.4 & 7699188 & 0.8 & 5489708 & 0.6 \\
\hline Built up area & 0 & 0.0 & 0 & 0.0 & 0 & 0.0 & 0 & 0.0 \\
\hline Cultivated land & 0 & 0.0 & 2925508 & 0.2 & 26735384 & 2.7 & 24673756 & 2.8 \\
\hline TOTAL & 1479258598 & 100.0 & 1514130280 & 100.0 & 1008694740 & 100.0 & 866358704 & 100.0 \\
\hline
\end{tabular}

The differences in local and global ESV raise uncertainties in decision making and planning for sustainable management of ecosystems. The logic behind is that, conservation benefit of ecosystems should overpass consequences of those ecosystems to local human livelihoods and wellbeing; also to fauna and flora resides inside and outside of that 
ecosystem. This phenomenon calls for balance in social, economic and environment in the phase of uncertainties whereby natural capital (environment) should be priotised and using global ESV for making such decisions.

\subsubsection{Changes of Economic Values of Ecosystem Services of LULCC Biomes' of Eastern Corridor of Selous-Niassa Ecosystem from 1986 to 2016}

The extent of changes of economic values of ecosystem services of land use land cover change (LULC) biomes including change in ESV, percentage ESV change and percentage annual rate of change are summarised on Tables $6 \&$. The increased and decreased amount is represented by negative $(-)$ and positive $(+)$ signs respectively.

Table 6 Changes in Local ESV from 1986 to 2016

\begin{tabular}{|c|c|c|c|c|c|c|c|c|c|}
\hline \multirow[t]{2}{*}{ LULC } & \multicolumn{3}{|c|}{$1986-1997$} & \multicolumn{3}{|l|}{$1997-2005$} & \multicolumn{3}{|c|}{$2005-2016$} \\
\hline & $\begin{array}{l}\text { Change in } \\
\text { ESV } \\
\text { (US\$)) }\end{array}$ & $\begin{array}{l}\% \\
\text { change }\end{array}$ & $\begin{array}{l}\text { Annual } \\
\text { Rate of } \\
\text { Change } \\
\text { (ESV/year) } \\
\text { (US\$)) }\end{array}$ & $\begin{array}{l}\text { Change in } \\
\text { ESV (US\$)) }\end{array}$ & $\begin{array}{l}\% \\
\text { change }\end{array}$ & $\begin{array}{l}\text { Annual } \\
\text { Rate of } \\
\text { Change } \\
\text { (ESV/year) } \\
\text { (US\$)) }\end{array}$ & $\begin{array}{l}\text { Change in } \\
\text { ESV } \\
\text { (US\$)) }\end{array}$ & $\begin{array}{l}\% \\
\text { change }\end{array}$ & $\begin{array}{l}\text { Annual Rate } \\
\text { of Change } \\
\text { (ESV/year) } \\
\text { (US\$)) }\end{array}$ \\
\hline CWD & $\begin{array}{l}- \\
16400979\end{array}$ & -27.7 & -1490998.1 & 139315050 & 54.8 & 17414381.3 & 13102425 & -13.4 & 1191129.5 \\
\hline OWD & -8892870 & -15.0 & -808442.7 & 121435545 & 47.8 & 15179443.1 & 67075533 & -68.6 & 6097775.7 \\
\hline BS & 99002022 & 167.2 & 9000183.8 & 75493656 & 29.7 & 9436707.0 & $-2.2 \mathrm{E}+08$ & 225.5 & -20041214.5 \\
\hline GL & 12499673 & -21.1 & -1136333.9 & -22713946 & -8.9 & -2839243.3 & 35359826 & -36.2 & 3214529.6 \\
\hline WTR & 5194023 & 8.8 & 472183.9 & -939948 & -0.4 & -117493.5 & 2106780 & -2.2 & 191525.5 \\
\hline BLT & 0 & 0.0 & 0.0 & 0 & 0.0 & 0.0 & 0 & 0.0 & 0.0 \\
\hline CL & -7186574 & -12.1 & -653324.9 & -58489478 & -23.0 & -7311184.8 & 5064434 & -5.2 & 460403.1 \\
\hline TOTAL & 59215949 & 100.0 & 5383268.1 & 254100879 & 100.0 & 31762609.9 & $\begin{array}{l}- \\
97744361\end{array}$ & 100.0 & -8885851.0 \\
\hline
\end{tabular}

CWD = Closed woodland, OWD = Open woodland, BS = Bushland, GL = Grassland, WTR = Water, BLT = Built Up area, and CL = Cultivated land

The results in Table 6 shows the decrease of total ESV for the period 1986 - 1997 (US\$ 59 million), 1997 - 2005 (US\$ 254 million) and increase of total ESV for the period 2005 - 2016 (US\$ 97 million); and Table 7 shows the increase of total ESV for the period 1986 - 1997 (US\$ 35 million), and decrease for the period $1997-2005$ (US\$ 505 million) and 2005 - 2016 (US\$ 142 million). These changes of ESV using local and global valuation coefficients must be integrated into national environmental policies to get decision models. For instance, we expected the total ESV to increase for the period 1986 - 1997 as the area were not easily accessible using roads, so transportation of valuable woods found in the area like Pterocarpus angolensis were impossible; but global ESV prove true while local ESV is opposite. Also, in these period of 1986 - 1997 national wide operation "uhai" were conducted to stop illegal harvesting of fauna and flora in the country. For the period 1997 - 2005 both local and global ESV shows the decrease in ESV while for the period 2005 2016 local ESV shows increase while global ESV shows decrease. The results affected by the value that given to each biome, for example closed woodland, open woodland and bushland given the same ESV so when Closed and Open woodlands changes to Bushland their ESV remain unchanged results to uncertainties.

Generally, annual changes of ESV for the period 1986 -2016 estimated as US\$ 7 million and US\$ 20 million using local and global ESV coefficients respectively. The differences between local and global ESV for the period 1986 - 2016 is $64.8 \%$ (US\$ 397 million) indicates global ESV is vital for macroeconomic policies. There are biomes in LULC types for the period 1986 - 2016 leads for degradation using local ESV includes closed and open woodlands which degraded for $63.1 \%$ and $83.3 \%$ respectively to bushland (21.3\%) and cultivated land (28.1\%); using global ESV, closed (45.1\%) and open (59.6\%) woodlands degraded to bushland (1.9\%) and cultivated land (4\%). 
Table 7 Changes in Global ESV from 1986 to 2016

\begin{tabular}{|c|c|c|c|c|c|c|c|c|c|}
\hline \multirow[t]{2}{*}{ LULC } & \multicolumn{3}{|l|}{$1986-1997$} & \multicolumn{3}{|l|}{$1997-2005$} & \multicolumn{3}{|c|}{$2005-2016$} \\
\hline & $\begin{array}{l}\text { Change in } \\
\text { ESV (US\$)) }\end{array}$ & $\begin{array}{l}\text { \% } \\
\text { change }\end{array}$ & $\begin{array}{l}\text { Annual } \\
\text { Rate of } \\
\text { Change } \\
\text { (ESV/year) } \\
\text { (US\$)) }\end{array}$ & $\begin{array}{l}\text { Change in } \\
\text { ESV (US\$)) }\end{array}$ & $\begin{array}{l}\% \\
\text { change }\end{array}$ & $\begin{array}{l}\text { Annual } \\
\text { Rate of } \\
\text { Change } \\
\text { (ESV/year) } \\
\text { (US\$)) }\end{array}$ & $\begin{array}{l}\text { Change in } \\
\text { ESV (US\$)) }\end{array}$ & $\begin{array}{l}\% \\
\text { change }\end{array}$ & $\begin{array}{l}\text { Annual } \\
\text { Rate of } \\
\text { Change } \\
\text { (ESV/year) } \\
\text { (US\$)) }\end{array}$ \\
\hline CWD & -33366936 & 95.7 & -3033357.8 & 283429200 & 56.1 & 35428650 & 26656200 & 18.7 & 2423291 \\
\hline OWD & -18092080 & 51.9 & -1644734.5 & 247054280 & 48.9 & 30881785 & 136461672 & 95.9 & 12405607 \\
\hline BS & 24474664 & -70.2 & 2224969.5 & 18663072 & 3.7 & 2332884 & -54499108 & -38.3 & -4954464 \\
\hline GL & -10409284 & 29.9 & -946298.5 & -18915368 & -3.7 & -2364421 & 29446408 & 20.7 & 2676946 \\
\hline WTR & 5447218 & -15.6 & 495201.6 & -985768 & -0.2 & -123221 & 2209480 & 1.6 & 200861.8 \\
\hline BLT & 0 & 0.0 & 0.0 & 0 & 0.0 & 0 & 0 & 0.0 & 0 \\
\hline CL & -2925508 & 8.4 & -265955.3 & -23809876 & -4.7 & -2976235 & 2061628 & 1.4 & 187420.7 \\
\hline TOTAL & -34871926.0 & 100.0 & -3170175.1 & 505435540 & 100.0 & 63179443 & 142336280 & 100.0 & 12939662 \\
\hline
\end{tabular}

CWD = Closed woodland, OWD = Open woodland, BS = Bushland, GL = Grassland, WTR = Water, BLT = Built Up area, and CL = Cultivated land

\subsection{Changes of Economic Values of Ecosystem Functions Based on LULC Type of Eastern Corridor of Selous- Niassa Ecosystem from 1986 to 2016}

The results in Tables 8 \& 9 shows estimated local and global annual economic value of the ecosystem functions and their relative changes from 1986 to 2016 in eastern corridor of Selous-Niassa ecosystem.

It was revealed that, for three decades there is loss of US\$322030356.1/US\$ 653841571 of ecosystem functions mostly from closed woodlands, open woodlands, grassland and water from 1986 to 2016 . Also, there is total annual local/global gain of ecosystem functions of US\$106434997/US\$118172260 from bushland and cultivated land from 1986 to 2016. The results further indicates that the gain of ecosystem functions comes from provisioning services and the degradation of ecosystem functions led by, supporting services, then regulatory services and lastly cultural services. These results imply that, there is encroachment of natural capital in the study area mostly on closed and open woodlands for valuable wood resources and for changes of land uses due to anthropogenic activities and reliance of dwellers to natural resources for their livelihoods.

\subsection{Estimate changes of economic value of ecosystem services of trees loss/gain of eastern corridor of Selous- Niassa ecosystem from 1986 to 2016}

The results in Tables 10 shows estimated economic value of the ecosystem services of trees loss from 1986 to 2016 in eastern corridor of Selous-Niassa ecosystem. The results indicate that for the period 1986 - 1997 annual ecosystem services of trees gained by US\$25293849 and US\$ 51459016 for local and global ESV respectively. Furthermore, for the periods 1997 - 2005 and 2005 - 2016 there was a loss of annual ecosystem services of trees of US\$260749608/US\$ 530481472 and US\$ 80177958/ US\$ 163117872 for local/global ESV respectively. The results implies degradation of ecosystem services for the period 1997 to 2016 due to high utilisation of forest resources especially valuable natural miombo woods found in the study ecosystem. The period 1986 - 1997 shows gain of ecosystem services due to famous countrywide operation "Uhai" occurred during this period, bad infrastructure especially roads, low human population and lack of markets for valuable miombo woods found in the study ecosystem. 
Table 8 Local economic values of ecosystem functions (US\$) from 1986 to 2016

\begin{tabular}{|c|c|c|c|c|c|c|}
\hline LULC & Ecosystem services & 1986 & 1997 & 2005 & 2016 & $\begin{array}{l}\text { Relative } \\
\text { change }\end{array}$ \\
\hline \multirow{5}{*}{$\begin{array}{l}\text { Closed } \\
\text { woodland }\end{array}$} & Provisioning services & 30106038.2 & 32302805.6 & 13642775.6 & 11887820.6 & 18218217.6 \\
\hline & Regulating services & 143169925.1 & 153616700.6 & 64878518.6 & 56532791.64 & 86637133.44 \\
\hline & Supporting services & 49866257.07 & 53504881.56 & 22597266.1 & 19690439.31 & 30175817.76 \\
\hline & Cultural services & 1548570.8 & 1661566.4 & 701746.4 & 611476.4 & 937094.4 \\
\hline & Sub-total & 224690791.2 & 241085954.2 & 101820307 & 88722527.95 & 135968263.2 \\
\hline \multirow{5}{*}{$\begin{array}{l}\text { Open } \\
\text { woodland }\end{array}$} & Provisioning services & 53170972.2 & 54362094.2 & 38096867.2 & 29112687.4 & 24058284.8 \\
\hline & Regulating services & 252855724.7 & 258520131.5 & 181170487.7 & 138446023.6 & 114409701.1 \\
\hline & Supporting services & 88069952.97 & 90042872.67 & 63101898.72 & 48220916.49 & 39849036.48 \\
\hline & Cultural services & 2734966.8 & 2796234.8 & 1959596.8 & 1497475.6 & 1237491.2 \\
\hline & Sub-total & 396831616.7 & 405721333.2 & 284328850.4 & 217277103.1 & 179554513.6 \\
\hline \multirow[b]{5}{*}{ Bushland } & Provisioning services & 57335933.2 & 44075347.8 & 33963634.2 & 63491561.8 & -6155628.6 \\
\hline & Regulating services & 272662288.1 & 209601283.3 & 161514807.5 & 301935514.9 & -29273226.84 \\
\hline & Supporting services & 94968602.82 & 73004379.03 & 56255801.67 & 105164502.9 & -10195900.11 \\
\hline & Cultural services & 2949200.8 & 2267113.2 & 1746994.8 & 3265829.2 & -316628.4 \\
\hline & Sub-total & 427916024.9 & 328948123.4 & 253481238.2 & 473857408.9 & -45941383.95 \\
\hline \multirow[b]{5}{*}{ Grassland } & Provisioning services & 46388052 & 51398586.45 & 60503545.35 & 46329444.45 & 58607.55 \\
\hline & Regulating services & 58849040 & 65205529 & 76756307 & 58774689 & 74351 \\
\hline & Supporting services & 10268960 & 11378146 & 13393718 & 10255986 & 12974 \\
\hline & Cultural services & 315968 & 350096.8 & 412114.4 & 315568.8 & 399.2 \\
\hline & Sub-total & 115822020 & 128332358.3 & 151065684.8 & 115675688.3 & 146331.75 \\
\hline \multirow[b]{5}{*}{ Water } & Provisioning services & 3088098 & 1704820 & 1955148 & 1394068 & 1694030 \\
\hline & Regulating services & 8409271.5 & 4642435 & 5324109 & 3796219 & 4613052.5 \\
\hline & Supporting services & 0 & 0 & 0 & 0 & 0 \\
\hline & Cultural services & 98739 & 54510 & 62514 & 44574 & 54165 \\
\hline & Sub-total & 11596108.5 & 6401765 & 7341771 & 5234861 & 6361247.5 \\
\hline \multirow{5}{*}{$\begin{array}{l}\text { Cultivated } \\
\text { land }\end{array}$} & Provisioning services & 0 & 5964220.44 & 54505311.12 & 50302279.08 & -50302279.08 \\
\hline & Regulating services & 0 & 763176 & 6974448 & 6436632 & -6436632 \\
\hline & Supporting services & 0 & 445186 & 4068428 & 3754702 & -3754702 \\
\hline & Cultural services & 0 & 0 & 0 & 0 & 0 \\
\hline & Sub-total & 0 & 7172582.44 & 65548187.12 & 60493613.08 & -60493613.08 \\
\hline \multicolumn{2}{|c|}{ GRAND TOTAL } & 1176856561 & 368304285.7 & 3365827921 & 3106281056 & 215595359 \\
\hline
\end{tabular}


Table 9 Global economic values of ecosystem functions (US\$) from 1986 to 2016

\begin{tabular}{|c|c|c|c|c|c|c|}
\hline LULC & Ecosystem services & 1986 & 1997 & 2005 & 2016 & $\begin{array}{l}\text { Relative } \\
\text { change }\end{array}$ \\
\hline \multirow{5}{*}{$\begin{array}{l}\text { Closed } \\
\text { woodland }\end{array}$} & Provisioning services & 90181476 & 96761808 & 40866408 & 35609508 & 54571968 \\
\hline & Regulating services & 128895746 & 138300968 & 58410068 & 50896418 & 77999328 \\
\hline & Supporting services & 212245292 & 227732336 & 96180536 & 83808236 & 128437056 \\
\hline & Cultural services & 25961334 & 27855672 & 11764572 & 10251222 & 15710112 \\
\hline & Sub-total & 457283848 & 490650784 & 207221584 & 180565384 & 276718464 \\
\hline \multirow{5}{*}{$\begin{array}{l}\text { Open } \\
\text { woodland }\end{array}$} & Provisioning services & 159271596 & 162839556 & 114117696 & 87205932 & 72065664 \\
\hline & Regulating services & 227645766 & 232745426 & 163107616 & 124642822 & 103002944 \\
\hline & Supporting services & 374851332 & 383248652 & 268580032 & 205242244 & 169609088 \\
\hline & Cultural services & 45850914 & 46878054 & 32852064 & 25104738 & 20746176 \\
\hline & Sub-total & 807619608 & 825711688 & 578657408 & 442195736 & 365423872 \\
\hline \multirow[b]{5}{*}{ Bushland } & Provisioning services & 171747576 & 132026004 & 101736756 & 190186524 & -18438948 \\
\hline & Regulating services & 245477596 & 188703834 & 145411626 & 271832254 & -26354658 \\
\hline & Supporting services & 404213992 & 310727868 & 239441052 & 447610708 & -43396716 \\
\hline & Cultural services & 49442484 & 38007486 & 29287854 & 54750666 & -5308182 \\
\hline & Sub-total & 870881648 & 669465192 & 515877288 & 964380152 & -93498504 \\
\hline \multirow[b]{5}{*}{ Grassland } & Provisioning services & 68328080 & 75708433 & 89119739 & 68241753 & 86327 \\
\hline & Regulating services & 58849040 & 65205529 & 76756307 & 58774689 & 74351 \\
\hline & Supporting services & 10268960 & 11378146 & 13393718 & 10255986 & 12974 \\
\hline & Cultural services & 789920 & 875242 & 1030286 & 788922 & 998 \\
\hline & Sub-total & 138236000 & 153167350 & 180300050 & 138061350 & 174650 \\
\hline \multirow[b]{5}{*}{ Water } & Provisioning services & 5806998 & 3205820 & 3676548 & 2621468 & 3185530 \\
\hline & Regulating services & 12684384 & 7002560 & 8030784 & 5726144 & 6958240 \\
\hline & Supporting services & 435024 & 240160 & 275424 & 196384 & 238640 \\
\hline & Cultural services & 2082105 & 1149450 & 1318230 & 939930 & 1142175 \\
\hline & Sub-total & 21008511 & 11597990 & 13300986 & 9483926 & 11524585 \\
\hline \multirow{5}{*}{$\begin{array}{l}\text { Cultivated } \\
\text { land }\end{array}$} & Provisioning services & 0 & 1717146 & 15692508 & 14482422 & -14482422 \\
\hline & Regulating services & 0 & 763176 & 6974448 & 6436632 & -6436632 \\
\hline & Supporting services & 0 & 445186 & 4068428 & 3754702 & -3754702 \\
\hline & Cultural services & 0 & 0 & 0 & 0 & 0 \\
\hline & Sub-total & 0 & 2925508 & 26735384 & 24673756 & -24673756 \\
\hline \multicolumn{2}{|c|}{ GRAND TOTAL } & 2295029615 & 672453453 & $\begin{array}{l}614536049 \\
4\end{array}$ & 5671477371 & 535669311 \\
\hline
\end{tabular}


Table 10 Economic value of ecosystem services of trees loss from 1986 to 2016

\begin{tabular}{|l|l|l|l|l|}
\hline Years & $\begin{array}{l}\text { Total area } \\
\text { converted (ha) }\end{array}$ & $\begin{array}{l}\text { Number of trees } \\
\text { loss/gain (in millions) }\end{array}$ & Local ESV (US\$) & Global ESV (US\$) \\
\hline $1986-1997$ & -25627 & -42 & -25293849 & -51459016 \\
\hline $1997-2005$ & +264184 & +437 & 260749608 & 530481472 \\
\hline $2005-2016$ & +81234 & +134 & 80177958 & 163117872 \\
\hline Total & +319791 & +529 & 315633717 & 642140328 \\
\hline
\end{tabular}

\subsection{Analyse economic value of ecosystem services of wood balance of corridor dwellers of eastern Selous- Niassa ecosystem}

Existing amount of trees from 1986 to 2016 (Table 11) used to estimate local and global ESV of wood balance by using estimated population of the study area in these periods.

Table 11 Economic value of ecosystem services of wood balance from 1986 to 2016

\begin{tabular}{|l|l|l|l|l|}
\hline Year & $\begin{array}{l}\text { Number of trees } \\
\text { (in millions) }\end{array}$ & $\begin{array}{l}\text { Estimated } \\
\text { human } \\
\text { population }\end{array}$ & $\begin{array}{l}\text { Local ESV (US\$) of } \\
\text { Wood balance } \\
\text { (US\$/capita/year) }\end{array}$ & $\begin{array}{l}\text { Global ESV (US\$) of } \\
\text { Wood balance } \\
\text { (US\$/capita/year) }\end{array}$ \\
\hline 1986 & 1041.9 & 312,081 & 2010.9 & 4091.0 \\
\hline 1997 & 1084.3 & 351,866 & 1839.0 & 3741.3 \\
\hline 2005 & 647.3 & 381,229 & 1016.0 & 2067.0 \\
\hline 2016 & 513 & 437,921 & 699.3 & 1422.7 \\
\hline
\end{tabular}

The results reveled in Table 9 shows that, local and global ESV of wood supply in the study area for the year 2016 is at least 25 times the average demand per year per capita. This implies that the area is still virgin interms of ESV of wood balance that means the ecosystem is still intact ecologically. However, the trend of ESV of wood supply from 1986 to 2016 shows dramatic disintegration of the study area ESV which implies tragedy of common and is the public property where there is no control policies or rules. The emergence of reviewing management and conservation strategies is of utmost action if we need sustainability of Selous-Niassa ecosystem

\section{Conclusion}

This study analysed economic values of ecosystem services of eastern Selous - Niassa ecosystem. The findings have revealed that the study area has undergone notable changes in terms of ecosystem services for the period between 1986 and 2016. Local knowledge revealed various factors associated to changes of ecosystem services that includes fire, cultivation, and deforestation. The main factors mentioned as contributing to fire were beekeeping, hunting activities, and local beliefs, while for deforestation include commercial logging and timbering, charcoals production, population growth, expansion of commercial farming and food crops production

The results indicate that land use and land cover change has a significant impact to the management of biodiversity and maintaining ecosystem services of the Selous-Niassa ecosystem. The greater increase of land use conversion alters ecosystem services, wildlife movements, gene flow and stochastic events like fire and climate change. The study concludes that the modification of the land use and cover has resulted in changes of ecosystem functions which influence behavioral changes of some wild animals due to changes of their habitats. The study highlights the effects of land use and land-cover on changes of ecosystem services of trees loss/gain and ecosystem services of wood balance of the corridor dwellers which shows unsustainable supply. 


\section{Recommendations}

The study provides the following recommendations for sustainable supply of ecosystem services of eastern Selous Niassa ecosystem:

- $\quad$ The Government through responsible Ministry has to formulate user friendly guidelines for protection of wildlife corridors as stipulated in Tanzania Wildlife Conservation Act No. 5 of 2009;

- $\quad$ The Government through responsible Ministry has to formulate new and enhancing existing wildlife management areas (WMAs), participatory forests managements (PFMs) and joint forests managements (JFMs) so as accrued benefits should be higher than protection costs of the existing resources;

- $\quad$ The Government through responsible Ministry has to formulate land use plans of the corridors so as to protect wildlife routes within the corridors;

- The public have to use alternatives wood resources so as offset the supply deficit of ecosystem services and attain sustainability

\section{Compliance with ethical standards}

\section{Acknowledgments}

My frank appreciation to the management of The Mwalimu Nyerere Memorial Academy for their technical and financial support during this study. Special thanks are also extended to the management of Tanzania Wildlife Authority (TAWA), Selous Game Reserve, Lukwika-Lumesule and Msanjesi Game Reserves, Liwale WMA (MAGINGO), Nachingwea and Masasi proposed WMA (NDONDA), Nanyumbu proposed WMA (MCHIMALU), District councils of Liwale, Nachingwea, Masasi and Nanyumbu in Tanzania especially Wildlife and Forest Staff for their kindly acceptance and positive cooperation they provided during data acquisition.

\section{Disclosure of conflict of interest}

The author has no any conflict of interest for publishing this article

\section{References}

[1] COP. Report of the tenth meeting of the conference of the parties to the convention on biological diversity. Nagoya. Contract No. 27. 2010.

[2] Costanza R, Darge R, de Groot R, Farber S, Grasso M, Hannon B, Limburg K, Naeem S, Oneill RV, Paruelo J et al. The value of the world's ecosystem services and natural capital. Nature. 1997; 387: 253-260.

[3] Costanza R, Groot RD, Sutton P, Ploeg SVD, Anderson SJ, Kubiszewski I, Farber S, Turner RK. Changes in the global value of ecosystem services. Glob. Environ. Chang. 2014; 26: 152-158.

[4] De Groot R, Brander L, van der Ploeg S, Costanza R, Bernard F, Braat L, Christie M, Crossman N, Ghermandi A, Hein $\mathrm{L}$ et al. Global estimates of the value of ecosystems and their services in monetary units. Ecosyst. Serv. 2012; 1: 50-61.

[5] Downing M, Ozuna T. Testing the reliability of the benefit function transfer approach. JEnvironEcon- Manage. 1996; 30(3): N316-22.

[6] Ecosystem Assessment, M. Ecosystems and Human Well-being: General Synthesis; In Island Press: Washington, DC, USA. 2005.

[7] Elliot S, Duncan S, Malone N. New Nature of Business: How Business Pioneers Support Biodiversity and Ecosystem Services. 2014.

[8] Farber S, Costanza RDL, Erickson J, Gross K, Grove M, Hopkinson CS, Kahn J, Pincetl S, Troy A, Warren P. Linking ecology and economics for ecosystem management. Bioscience. 2006; 56: 121-133.

[9] Food and Agriculture Organization. Agriculture and Climate Change: FAO Role; In Viale delle Terme di Caracall; FAO: Rome, Italy. 1997.

[10] Gashaw T, Tulu T, Argaw M, Worqlul AW, Tolessa T Kindu, M. Estimating the impacts of land use/land cover changes on Ecosystem Service Values: The case of the Andassa watershed in the Upper Blue Nile basin of Ethiopia. Ecosyst. Serv. 2018; 31: 219-228. 
[11] Hanson C, Ranganathan J, Iceland C, Finisdore J. The Corporate Ecosystem Services Review: Guidelines for Identifying Business Risks \& Opportunities Arising from Ecosystem Change. Washington, DC: World Resources Institute. 2012.

[12] Hein L, Van Koppen K, Groot RS, Van Ierland E. Spatial scales, stakeholders and the valuation of ecosystem services. Ecol. Econ. 2016; 57: 209-228.

[13] Kahn JR. Economic Approach to environmental and natural resources 3rd ed. Nashville, TN: South- Western Publishers. 2005.

[14] Kindu M, Schneider T, Teketay D, Knoke T. Changes of ecosystem service values in response to land use/land cover dynamics in Munessa-Shashemene landscape of the Ethiopian highlands. Sci. Total Environ. 2016; 547: 137-147.

[15] Kreuter UP, Harris HG, Matlock MD, Lacey RE. Change in ecosystem service values in the San Antonio area, Texas. Ecol. Econ. 2001; 39: 333-346.

[16] Kubiszewski I, Costanza R, Anderson S, Sutton P. The future value of ecosystem services: Global scenarios and national implications. Ecosyst. Serv. 2017; 26: 289-301.

[17] Laurans Y, Rankovic A, Bille R, Pirard R, Mermet L. Use of ecosystem services economic valuation for decision making: Questioning a literature blindspot. J Environ Manage. 2013; 119: 208-19.

[18] Liu S, Costanza R. Ecosystem services valuation in China. Ecol. Econ. 2017; 69: 1387-1388.

[19] Liu S, Costanza R, Farber S, Troy A. Valuing ecosystem services: Theory, practice, and the need for a transdisciplinary synthesis. Ann. N. Y. Acad. Sci. 2010; 1185: 54-78.

[20] Martin-Lopez B, Gomez-Baggethun E, Garcia-Llorente M, Montes C. Trade-offs across value-domains in ecosystem services assessment. Ecological Indicators. 2013; 37: 220-8.

[21] Millennium Ecosystem Assessment. Ecosystems and Human Well-being: Synthesis. Washington, DC.: Island Press. 2005.

[22] Miller DL. Federal Emergency Management Agency of the USA Mitigation Policy -FP-108-024-01, Consideration of Environmental Benefits in the Evaluation of Acquisition Projects under the Hazard Mitigation Assistance (HMA) Programs. 2013; 7.

[23] Msofe NK, Sheng L, Li Z, Lyimo J. Impact of Land Use/Cover Change on Ecosystem Service Values in the Kilombero Valley Floodplain, South eastern Tanzania. Forests. 2020; 11(109): 2-17.

[24] Pascual U, Muradian R, Brander L, Gómez-Baggethun E, Martín-López B, Verma M. The economics of valuing ecosystem services and biodiversity. In: Kumar P, editor. The Economics of Ecosystems and Biodiversity Ecological and Economic Foundations. London and Washington: Earthscan. 2010.

[25] Raudsepp-Hearne C, Peterson GD, Tengo M, Bennett EM, Holland T, Benessaiah K, et al. Untangling the Environmentalist's Paradox: Why Is Human Well-being Increasing as Ecosystem Services Degrade? BioScience. 2010; 60(8): 576-89.

[26] Richardson L, Loomis J, Kroeger T, Casey F. The role of benefit transfer in ecosystem service valuation. Ecol. Econ. 2015; 115: 51-58.

[27] Schmidt S, Manceur AM, Seppelt R. Uncertainty of Monetary Valued Ecosystem Services- Value Transfer Functions for Global Mapping. PLoS ONE. 2016; 11(3): e0148524.

[28] SEEA. System of Environmental-Economic Accounting Website 2015 [Accessed July 2020].

[29] Smith KV, Pattanayak SK. Is Meta-Analysis a Noah's Ark for Non-Market Valuation? Environmental and Resource Economics. 2002; 22: 271-96.

[30] TEEB Foundations. The Economics of Ecosystems and Biodiversity: Ecological and Economic Foundations; Earthscan: London, UK. 2010.

[31] TEEB. The Economics of Biodiversity and Ecosystem Services Website 2015 [Accessed November 2015].

[32] ten Brink P, Hansjürgens B, Kettunen M, Lehmann M, Neßhöver C, Schröter-Schlaack C, et al. The Economics of Ecosystems and Biodiversity in National and International Policy Making. ten Brink P, editor. London and Washington: Earthscan. 2011. 
[33] Tolessa T, Senbeta F, Kidane M. The impact of land use/land cover change on ecosystem services in the central highlands of Ethiopia. Ecosyst. Serv. 2017; 23: 47-54.

[34] Troy A, Wilson MA. Mapping ecosystem services: Practical challenges and opportunities in linking GIS and value transfer. Ecol. Econ. 2007; 60: 435-449.

[35] Turner RK, Paavola J, Cooper P, Farber S, Jessamy V, Georgiou S. Valuing nature: Lessons learned and future research directions. Ecol. Econ. 2002; 46: 493-510.

[36] Wang X, Dong X, Liu H, Wei H, Fan W, Lu N, Xu Z, Ren J, Xing K. Linking land use change, ecosystem services and human well-being: A case study of the Manas River Basin of Xinjiang, China. Ecosyst. Serv. 2017; 27: 113-123.

[37] Wang Y, Dai E, Yin L, Ma L. Land use/land cover change and the effects on ecosystem services in the Hengduan Mountain region, China. Ecosyst. Serv. 2018; 34: 55-67.

[38] WAVES Wealth Accounting and the Valuation of Ecosystem Services Website 2015 [Accessed July 2020].

[39] Zella AY, Saria J, Lawi Y. Analysis of Spatial and Temporal Changes in Land Uses and its Implications to the Conservation of Eastern Selous-Niassa Transfrontier Conservation Areas (TFCA). Journal of Environmental Science and Public Health. 2017; 1(3): 84-91.

[40] Zhang F, Yushanjiang A, Jing Y. Assessing and predicting changes of the ecosystem service values based on land use/cover change in Ebinur LakeWetland National Nature Reserve, Xinjiang, China. Sci. Total Environ. 2019; 656: 1133-1144.

[41] Zorrillamiras P, Palomo I, Gómezbaggethun E, Martínlópez B, Lomas PL, Montes C. Effects of land use change on wetland ecosystem services: A case study in the Doñana marshes (SW Spain). Landsc. Urban Plan. 2014; 122: $160-174$. 